\title{
PANORAMIC VIEW OF ECONOMIC CRISES IN THE UNITED STATES 1819-1857: HISTORICAL PERSPECTIVE
}

\author{
Fethia Braik \\ Hassiba Benbouali University of Chlef, ALGERIA, \\ e-mail: fethiadove@yahoo.fr , f.braik@univhb-chlef.dz
}

\begin{abstract}
Eager to understand and to overcome the 2007 crisis, economists worldwide are struggling to provide better understanding of past panics. Researches revealed that the recent crisis and the Great Depression, the most severe ever witnessed by the United States, share some similarities. Most of the financial calamities started in the United States and spread internationally since they occurred in a world of interconnected trade. In narrative histories of US financial panics, little is found about similarities and differences of the panics. "All is forgotten until another storm comes". Contemporary commentators and economic scholars do not seem to have the same identification of the events leading up to banking panics. The result is revealed in the number of panics they give when referring to US economic history. The most recent definition of banking panic is provided by Calomiris and Gorton. A banking panic may occur when depositors ask for immediate redemption for cash. My paper studies most panics, be they major or minor, from 1819 to 1857; with attributing more importance to the latter being focal point in the economic history of the country. My work is a combination of historiography, clinical survey, and analysis. It comprehends history of the panics, analysis of causes basically failures of companies and banks, and stamen of similarities and differences.
\end{abstract}

Keywords: Bank failure, bank panic, economic crisis

\section{INTRODUCTION}

Economic history of the United States reveals that the country suffered serious financial instability. Prior to the Civil War, the country witnessed the most serious recessions in 1837 and 1839. During the Civil War, the country was hit by a more severe stock crash in 1857. By the end of the nineteenth century and the beginning of the twentieth century, the United States' history was characterized by two major episodes of banking panics in 1892 and 1907. 


\section{ECONOMIC CRISES IN THE UNITED STATES FROM 1819 TO 1857}

The newly independent country faced its first major financial crisis in 1819 which was partially due to international events. Soon after the Napoleonic Wars ${ }^{1}$, European agriculture recovered. Hence their demand for American agricultural products decreased. Additionally, exportation of precious metals from Mexico to Europe declined because of wars and revolutions at that period of time. Consequently, European governments accumulated all the specie. American bankers started issuing false banknotes to compensate for the absence of international money supply.

Other explanations of the panic have been offered by different scholars. The panic was an outcome of the failure of the nationwide economic system because of the War of $1812^{2}$. Government borrowed and spent big amounts of money to finance the War. Banks' reserve of specie had been strained, a fact that led to the suspension of payments violating the rights of depositors. This culminated in banks runs and bankruptcies.

Other economists pointed out that the panic reflected the failure of the market economy in the country. Market institutions moved from boom to bust cycle. Banks gave credits in return of low interest rates. Many businesses and investments were promoted leading to a growth in economy. Foreign goods importation decreased because of the blocking of foreign trade; and prices of domestic products rose due to the rapid expansion. This led to overinvestment and excess in production. Subsequently, investors lost their money, and employers lost their jobs leading the country to a crisis.

Rockoff (2013) contended that the panic was due to real estate speculation. Many state private banks and branches of the US Second Bank were bestowed with the power to control land mortgages. Similarly, branches could redeem notes issued by any other branch without any restriction. Western branches, such as Cincinnati, made large loans in currencies which were to be redeemed by other branches. As a matter of fact, the U S Second Bank ran out of specie. It then reduced its loans portfolio. Immediately, western chartered banks of Cincinnati and Kentucky suspended specie payments.

Whatever might be the explanation provided, the panic caused unemployment and distress for money. Benjamin Brand, a merchant, described the situation as follows:

We have gloomy times here, many failures have taken place, and many more soon expected. At this time, there is very little credit business done. Confidence in each other's ability to pay is very slight...

President Monroe (1758-1831), the fifth President of the United States, as a measure to overcome the panic, limited governmental action to ensure fiscal stability. Public policy, bank debt and debt relief, internal improvements, and tariff protection were all reviewed. Appropriations for internal improvements, for instance, would not be approved without a constitutional law. The panic wrought great changes in different domains. Two important Acts were enacted.

To start with, there was the Land Act of 1820 . Some farmers brought public lands from Government on credit. Thanks to the Act, the number of acres, which farmers were to purchase, was reduced to eighty instead of 160 . The cost also was reduced from $2 \$$ /acre to $1.25 \$$ /acre. Those purchasers were required to pay only one fourth of the total price. What remained was to be paid in three annual instalments; otherwise, the land might be forfeited. Nonetheless, most of the purchasers proved unable to complete their payments. Congress, therefore, delayed the lands' forfeiture leaving them with a heavy burden of debts. With the panic, however, these debts became a severe federal dilemma.

As a remedy to this serious problem of land debts, President Monroe presented the issue in front of Congress. Soon after, resolutions were introduced in Congress. Senator Richard M. Johnson of Kentucky (1780-1850) suggested that purchasers unable to pay would give over the possession of the land and be entitled the ownership of only a part of it, that is the part they were able to pay. Similarly, Senator John W. Walker of Alabama (1783-1823) presented another resolution calling for the complete cancellation of any bank interest on payment instalments. Although the measure relief met opposition from some southern

\footnotetext{
${ }^{1}$ These were a series of armed conflicts of the French Empire, led by Napoleon, against an array of European powers that took place from 1803 to 1815.

${ }^{2}$ It was a conflict between Great Britain and the United States due to the British attempts to restrict American trade. Nevertheless, the War ended after the ratification of Treaty of Ghent on February $17^{\text {th }}, 1815$. The war is considered by Americans as the "Second war of independence"

${ }^{3}$ Clyde A. Haulman, The Panic of 1819, America's first Great Depression, in Financial History, Winter 2010, www.moaf.org. p 20
} 
IJASOS- International E-Journal of Advances in Social Sciences, Vol. III, Issue 8, August 2017

states, it gained support of all sections of the country and was referred to as the Relief Act of 1821 .

Free trade was seriously blamed for the panic. Hence, protective tariff for American industry was increasingly supported. Duties on cotton and woollen goods were supposed to fall during the crisis period. Thus, for the end of protecting domestic manufactures, the Convention of Friends of National Industry ${ }^{4}$ asked for an increase of duties on imported products. According to the members of the Convention, the cause of the panic was the excessive importation of "worthless fabrics" from China and East India.

Free trade, according to Mathew Carey $^{5}$, might cause unemployment, factories' bankruptcies, and banks runs. Protective trade, on the other hand, would promote a prosperous domestic industry and a secure national market, and employment. Therefore, imposing high duties on foreign products was highly recommended. As a subsequent consequence, a bill of protective tariff was introduced during the congressional session in 1820 , usually referred to as the Baldwin Bill. ${ }^{6} \mathrm{It}$, nevertheless, gained only one vote in the Senate; thus, it was withdrawn. Nonetheless, manufacturers and farmers signed petitions to Congress for tariff protection for industry.

Slowly and gradually many states, associations, and communities joined the Protectionist movement. Ohio, Missouri, Delaware, Maryland, and New York had their leading protectionists. All of them worked tirelessly for protection and gave preference to domestic products like iron, salt, cotton, and woollen industries. While some states exempted manufacturers from any imposed taxes and debt-paying process, some others doubled taxes on foreign goods sellers. Such resolutions and states actions re-stressed the bottle over the Baldwin Bill, which was at last voted for in Congress despite oppositions it encountered.

"Thanks" to the panic, many federal as well as states actions were set forth and enhanced for the sake of improving the young nation's monetary system. Being the primary source for depression, bank credits were restricted. Although the panic ended in 1823, it influenced economy in later years in the United States of America. Issues of banking system, tariff protection, and debt collection existed before the panic and well after it was over.

In the spring of 1837 , US economy was gripped by another financial crisis. By 1836, the Suffolk Bank of Boston, New England, became the clearer of all banknotes; acting as a national bank. However, most of US banks witnessed widespread suspensions of specie payments. The first bank to suspend payment was Natchez in the Mississippi, followed by Alabama, New York, Philadelphia, Baltimore, and New Orleans. By the end of May 1837, all the banks suspended payments. The causes of this bank panic are various and manifold. Historians and economists, trying to disentangle the real cause of the panic, blamed President Andrew Jackson's, the seventh president of the United States, refusal to pass the bill of rechartering the Second Bank of the United States. For them, such refusal deprived the B.U.S of its powers and provided state banks with the public money. ${ }^{7}$ S. Trask pointed out to the banking expansion that followed the President's opposition to the renewal of the Bank. From 1833 to 1837, the number of banks mushroomed with a rate of \%56. Local legislatures urged the need to charter new banks for the sake of making profits from public deposits. Such expansion would inflate the money supply significantly, concluded Trask.

Some economists related the panic to the failures of Hermann, Briggs and Co., and J.L. and S. Josephs and Co. The cotton factor in New Orleans was a client of bill broker in New York. The latter blamed its failure on the former's failure as they were closely tied. While the former failed on March $3^{\text {rd }}, 1837$, the latter failed a couple of weeks after; citing that the New Orleanians' suspension was the direct cause to their embarrassment. In any case, the failure of these two companies does not at all discard attributing significance to the relationship between the banking system and the panic.

The Treasury of the Jackson Administration issued the Deposit Act in June $23^{\text {rd, }} 1836$, also referred to as Distribution Act; ordering interbank transfers to distribute $\$ 28$ million of federal surplus. The latter was to be returned to states in proportion of their populations, causing inflation. Consequently, the number of deposit

\footnotetext{
${ }^{4}$ The Convention of Friends of National Industry was founded in 1819 by protectionist leaders from nine states the main proposal of which was to call for more tax imposition on imported goods.

${ }^{5}$ Mathew Carey, a Philadelphia printer, is the organizer and the secretary of the Convention and the writer of its proposal.

${ }^{6}$ Henry Baldwin was a representative in Congress from Pittsburgh, and a manufacturer of iron.

${ }^{7}$ H.A. Scott Trask, The Panic of 1837 and the Contraction of 1839-43: a Reassessment of its Causes from an Austrian Perspective and a Critique of Free Banking Interpretation, Kurzweg Fellow, Mises Institue, March 2002, pp 1.
} 
banks increased extensively. ${ }^{8}$ According to others, banks were put under more vulnerability to runs by an executive order, issued in 1836, referred to as Specie Circular. The latter provided that payment for public land purchase would only be in specie. Tandem, these two measures made of banks running out of specie leading to the panic, in motion. Still other historians claimed that the panic was but due to falling cotton prices, a culmination of the enactment of Specie Circular, leading to a decrease of farm incomes and an increase of mortgage defaults.

Whatever might be the cause or the causes of the panic, the "severe depression" led to the decline of both imports and exports. Additionally, thousands of workers connected with building trade lost their jobs. This slowdown, the watershed event in the history of US economy, lasted for almost five years. Actually, the Unites States witnessed a short recovery in 1839. In 1838, after the Specie Circular was repealed, northern states increased their construction of new canals and railroads. Likewise, southern and western states propelled their banks' capital with $\$ 20$ million. Even states in the far west invested persistently in railroad and canal constructions. Soon after this recovery, the United Sates did sink into a four-year deflation. The economic literature provides but little explanation about the crisis, the longest banking panic hitherto. Unlike the 1837 panic, the 1839 crisis was a culmination of domestic policies rather than of international forces. Wallis (2001 and 2002) stressed the conclusion that the events leading up to the two panics followed different paths. He believed state excessive borrowing and the collapse of internal improvement investments were catalyst that stimulated the crisis.

America's first Great Depression, the panic of 1839, is usually associated with the failure of the Bank of Pennsylvania. The latter invested its funds in cotton expecting its prices to rise. However, the Bank failed due to its losses of state government holdings. Additionally, the Bank was engaged in state bonds market. It forwarded bonds to be invested in Great Britain. Soon after, however, bonds prices fell due to the decrease of land values. It also was subject to pressure from creditors in the United States. Thus, the bank declined. Similar to U.S.B. of Pennsylvania, the Banking Company and the Morris Canal of New Jersey was ignited by financial failures. For internal improvement purposes and to increase its capital, the bank credited in advance $\$ 3.000 .000$ million from the state of Indiana. Then, it was to furnish a fund of $\$ 100.000$ monthly. Thus, in August 1839, the Bank defaulted. Henceforth, projects in Indiana halted leading up to a decrease of land boom which, by its turn, led to the fall of land prices devastatingly. Furthermore, the Morris Bank's failure deprived Indiana from any available funds to make its semi-annual interest payment.

The Morris Bank was chartered to build the Morris Canal across northern New Jersey that connected it to New York, as it invested in Western state bonds. It expected making profits of bonds issued by states for internal canal and railroad industries. Bonds' price, however, depended on hopeful real estate, contended Rockoff. Similarly, so many other northern states, the focal point of 1839 downturn, borrowed to embark in infrastructure investment in railroads and canals. Southern states, however, borrowed to invest in or create banks. Stockholders could borrow from those banks to buy new lands. And so, between the year 1837 and 1838, borrowing plummeted. Actually, much of the borrowing was from foreign investors who expected making future revenues. States, borrowers, applied new tax policies whereby they could levy taxes for debt services. This debt payment policy, among many other policies adopted for the same end, proved unsatisfactory for states to pay back their debts.

Economic scholars related state finances intricacy, shaped in its borrowing measures, to the crisis of 1839 . It spread mainly in southern and western banks since states were closely tied to their banks. The latter lost its deposits and specie continuously from 1839 to 1841 . During the period between January $1^{\text {st }}, 1839$ and January $1^{\text {st }}, 1840$, holdings in banks fell from $\$ 43$ million to $\$ 34$ million $^{9}$. As a subsequent consequence, the supply of money fell by 22 percent, leading to deflation. Wallis (2001) came to the conclusion that the tighter was the state close to their banks the deeper was the economic contraction. In the defaulted states, both of holdings and deposits declined by 35 and 54 percent respectively. In the states which were not closely associated with their banks, the decline was less serious. Holdings lowered at 14 percent, and deposits with only 18 percent. Wallis (2001) believed that during 1839, there was but a brief domestic crisis. Domestic exchange rate reached 6 percent, money supply decreased, and prices fell devastatingly. There was, however, no international payment crisis, as the exchange rate remained steady. State defaults impeded the entire financial system.

At the Federal legislative level, this state default promoted debates among leaders as to what shape they would adopt to determine governmental economic policies. To cure such weaknesses, many constitutional

\footnotetext{
${ }^{8}$ Peter L. Rousseau , Jacksonian Monetary Policy, Specie Flows, and the Panic of 1837, pp458

${ }^{9}$ Wallis $\mathrm{p} 12$
} 
reforms were enacted to determine the relationship between state and economy. State investments were restricted; the way debts were issued by local government was altered, and debt amount was limited; and taxation policy was changed.

Although states adopted new constitutions to avoid repetition of the mistakes that led to the crisis, $U \mathrm{~S}$ economic peacetime was cut every once and while, with some regularity, by bank runs, panics, and closures. For example, the panic of 1837 took place during the period of the existence of the US Second Bank, unlike the panic of 1857 which occurred during the era of an absence of National Bank (free banking era from 1837-1863); as there was rather a local panic during 1854 in New York. While the former was triggered by a shock about the failure of the nation-wide financial sector, the latter sparked after the insolvency of one local bank.

Generally speaking, prior to panics, bad news about banks assets, price declines, and commercial failures would spread to make people aware that an important shock would occur. This negative information that depositors would learn about banks might lead them to remove their deposits from banks hastily. Kauffman (1994) concluded, however, that bank runs are ignited when depositors force their banks to pay back the value of their deposits. Thus, bank runs spread. Such "non-informational contagion" led to a panic during 1854 that started when news about insolvency of one local bank spread over the state of New York. ${ }^{10}$

The Emigrants Industrial Savings Bank was the eighth mutual savings bank to be charted in 1850 to manage Irish immigrants' money. On September $30^{\text {th }}, 1850$, it started receiving deposits. By 1856, the EISB became one of the largest savings banks in New York, as it had 4.291 accounts with $\$ 1$ million as deposits. ${ }^{11}$ Deposits of EISB's clients were higher than $\$ 500$ for which the bank paid an interest rate of 5 percent for each. For accounts under than $\$ 500$, the bank paid 6 percent of interest for each. The bank was chartered to invest in purchasing state and municipal bonds, call loans, and mortgages; as it could make call loans to brokers. To be able to make all those investments, the EISB held but little cash of its assets. For its liquidity, it relied more on deposits.

The failure of Knickerbockers Savings Bank prompted runs in other savings banks in New York. For instance, the EISB's investments decreased by only 14 percent; while its real estate market did not undergo any change. Such decline would threaten the Emigrant. Henceforth, excited by rumors, depositors would run to withdraw their deposits, reasonably. Only a few of them closed their accounts as they did not know that such closure would deprive them of the payments of dividends. White and O Grada (2003) concluded that the less experienced and the less informed depositors were the first to close their accounts. Closure of an account might cause an outflow of $\$ 112 .^{12}$ The run gradually died out thanks to the bank's steady payments to its depositors. The local panic of 1854 was sparked by contagion and dramatic response to news events among depositors. The nationwide panic of 1857 , however, was led by business leaders.

The early 1850's were characterized by new investments in roads, the most capital-intensive industry of that time. This changed the securities markets in the United States. Securities traded by investors consisted mainly of railroads bonds and stocks. Competition between old roads in the West and the newly built lines led to the former's earnings falling. The new lines, however, provided investors with important speculative opportunities; as they sought expansion. Subsequently, many private companies were forced into default. In the midst of this "railroad fever", speculative railroad securities fell hand in hand with the fall of the western land values leading to a banking panic; and many industries such as steel and coal witnessed a slowdown.

The year 1857 witnessed a general commercial distress. Subsequently, many bank depositors converted their debt into specie promptly. Bonds values were depressed as banks were compelled to sell them to meet the depositors' urgent demand. The discount rate that banks could charge in return of the conversion of notes into specie was restricted. Additionally, brokers were forced to sell their holdings at very lower prices as city banks refused to roll over their debts. All in all, railroads failures, land values decline, the prompt drain of specie from banks are arguably the destabilizing elements that led to the panic of 1857.

Actually, the drain witnessed by New York bank affected many other banks especially those which were related directly to it. Furthermore, more banks were under the threat of runs because of the suspension of

\footnotetext{
${ }^{10}$ For Calomiris and Gorton, the bank run that occurred in New York in 1854, is not classified as a banking panic so long as it was at the local level. White and O Grada (2003) studied it, however, as a banking panic since it meets the definition of the banking panic presented by Calomiris and Gorton.

${ }^{11}$ Eugene N. White; Cormac O Grada, The Panics of 1854 and 1857: a View From the Emigrants Industrial Savings Bank, the Journal of Economic History 213-240, Cambridge University Press, 2003, pp 216.

${ }^{12}$ lbid., pp 227
} 
specie in New York, Philadelphia, and Baltimore banks, respectively. Suspensions of some banks were defensive. Other banks remained open and confronted the storm. The failure to suspend led them to more serious consequences than suspension.

Other scholars blamed the Ohio Life Insurance and Trust Company (OLITC) for the panic. It foreshadowed the weakness of the economic system at that time. The company's assets were mainly land securities and loans to railroads. Out of its $\$ 4.8$ million in assets, the company invested $\$ 3$ million, over half its capital, in railroads. Ohio Life's connection to a faltering railroad company can easily explain why it was the first to go bankrupt, reflecting the failure of railroads especially in the West and land securities. This could be related to political uncertainty as to whether or not Kansas and Nebraska were slave states. The failure of the company was officially announced on August $24^{\text {th }}, 1857$. A week after, railroads share prices decreased. Actually, the OLITC was not only a trust company but also a large shadow bank. It provided local banks with funds on deposits with attractive interest rates. Its default caused a drop in stock market. Additionally, note holders and depositors run to convert their bank notes into specie. Consequently, banks' deposits and notes fell from $\$ 8.7$ million to $\$ 7.8$ million and from $\$ 64.2$ million to $\$ 56.9$ million, respectively. ${ }^{13}$ Hence, the panic did spark due to a cluster of failures; banks suspended depositors' payment and bankruptcies mushroomed.

New York bank's deposits as well as specie fell. By October $14^{\text {th }}$ of the same year, almost all banks over the country suspended payments. On the same day, railroads companies such as Michigan Central and Illinois Central proved unable to pay back their obligations. All this coincided with a decline in agriculture, basically in the Northwest. As early as 1856, wheat prices decreased precipitously due to the decline of export. Farmers liquidated their assets as they were heavily indebted because of land values' decline. Equally important, the panic was aggravated by the Civil War (1861-1865). Calomiris and Schweikart (1991) contended that the panic was triggered by the Dred Scott case. ${ }^{14}$ The Dred Scott Decision affirmed slave property, opened the western frontier to slavery, and lowered the interest in western railroad investments. Subsequently, the price of Western land dropped ${ }^{15}$, and the value of railroad securities plummeted. Prominent railroads companies closed. Likewise, the price of commodities fell drastically. Farmers, ironmasters, and manufacturers suffered bitterly from price decline.

The first three panics occurred during economic booms. The expansion of money supply through credits issuance promoted inflation. President James Buchanan (1791-1868) in describing the panic of 1857 stated in his first annual message,

It is apparent that our existing misfortunes have proceeded solely from our extravagant and vicious system of paper money and bank credits.... These revulsions must continue to occur at regular intervals.

The panic, in any case, did not last long. The fast recovery can be explained by the absence of a national bank at that time. Monetary inflation was at a lower scale and liquidations were rapid so long as there was not any national bank to issue more money. Coordination between and among banks proved satisfactory for states to cope with the panic. Capital-asset ratios of banks increased from 0.33 to 0.40 by February $1860 .^{16}$ Likewise, interbank net deposits increased. Resumption was hastened thanks to the coordination of Clearing House. Banks reserves increased as $\$ 7$ million of interior bank currency was to be redeemed at 20 percent per month. ${ }^{17}$ Although the antebellum South lacked Clearing House, states achieved coordination through establishing branch banking. Data about Southern states banks revealed a rise in ratios of deposits and loans; reflecting the branch banking system's success in overcoming the panic. Indeed, banks cooperative behaviors and the establishment of small banks facilitated the limitation of suspension and failures.

The election of the sixteenth president of the United States Abraham Lincoln (1809-1865) sparked political unrest which by its turn led to financial instability. Specie was drained from the North to the South since the latter repudiated its debts. Subsequently, banks in the South suspended specie payments. By 1861, banks reserves decreased because of heavy withdrawal of coin. In the course of time, banks throughout the nation suspended payments. In the midst of the Civil War, the United Sates reformed its economic structure for the

\footnotetext{
${ }^{13}$ Ibid., p 223

${ }^{14}$ In ruling over the case of Dred Scott V. Sanford, the Supreme Court's Chief Justice Roger B. Taney deprived Scott, his wife, and two daughters of their freedom, being properties of the Sanfords, on the light of the Fifth Amendment which stated that "No person shall be deprived of life, liberty, or property."

${ }^{15}$ In lowa, for instance, the land price per acre reached \$ 0.40 after the Dred Scott decision. Source: Smith and Cole (1935) qtd in Jenny B. Wahl, 2009, Dred, Panic, War: How a Slave Case Triggered Financial Crisis and Civil Union, US: Carleton College, pp27

${ }^{16}$ Calomiris, p824.

${ }^{17}$ lbid. P 825
} 
end of resolving the financial crisis. Monetary system was established by National Banking Acts of $1863^{18}$ and 1864 passed by Radical Republicans. Additionally, they raised taxes to enable government to finance the infrastructure expansion. To finance the War, northern states created the National Banking System, and raised the money supply via funnelling states with cheap greenback currency, as people were unable to convert their notes or bills into specie. The fiat currency, or the greenback, was the printed paper money with future repayment. ${ }^{19}$ Greenback value was depreciated as it reached 40 cents by June $1864 .{ }^{20}$ The NBS compelled banks to have licenses to produce currency receivable as taxes. In any case, all banks were free to use greenbacks. This led to explosion of American money supply. ${ }^{21}$ The monetary increase promoted an increase of $110 \%$ in wholesale prices during the war. Similarly, the US debt rose to $30.79 \%$. The country passed through a short recession. The Civil War, like any other war, had negative impacts on the economy of the United States, as the latter required factories to construct war equipments, rather a short-lived production. Economic downturn, after the war, would be inevitable as factories had to re-adjust their long term productions.

\section{CONCLUSION}

The table below summarizes the most important economic downturns witnessed by the United States during the first half of the nineteenth century. It is easy to deduce that the common reason behind the panics is overinvestment. As history repeats itself; it is highly recommended to learn from past experiences to secure prosperous future.

\begin{tabular}{|c|c|c|c|}
\hline $\begin{array}{l}\text { Year of } \\
\text { Panic }\end{array}$ & Institution & Type of Institution & $\begin{array}{c}\text { Excessive } \\
\text { Investment } \\
\text { in... }\end{array}$ \\
\hline \multirow[t]{4}{*}{1819} & $\begin{array}{c}\text { Cincinnati branch of the Second } \\
\text { Bank of the U S }\end{array}$ & Federal Charter & \multirow[t]{4}{*}{ Real estate } \\
\hline & Bank of Kentucky & \multirow[t]{2}{*}{ State Banks } & \\
\hline & Banks in Western Pennsylvania & & \\
\hline & Banks in Cincinnati & $\begin{array}{l}\text { State and Private } \\
\text { Banks }\end{array}$ & \\
\hline \multirow[t]{2}{*}{1837} & J. L. And S. Josephs, Co. New York & Bill Broker & \multirow{2}{*}{$\begin{array}{l}\text { Real estate+ } \\
\text { cotton }\end{array}$} \\
\hline & $\begin{array}{c}\text { Hermann, Briggs and Co. New } \\
\text { Orleans }\end{array}$ & Cotton Factor & \\
\hline \multirow[t]{2}{*}{1839} & $\begin{array}{c}\text { Bank of the United States of } \\
\text { Pennsylvania }\end{array}$ & \multirow[t]{2}{*}{ Investment Bank } & \multirow{2}{*}{$\begin{array}{c}\text { State } \\
\text { government } \\
\text { bonds }\end{array}$} \\
\hline & $\begin{array}{c}\text { Morris Canal and Banking } \\
\text { Company New Jersey }\end{array}$ & & \\
\hline \multirow[t]{3}{*}{1854} & $\begin{array}{l}\text { Ellis and Sturges, Goodman Co., } \\
\text { Smead and Co., Cincinnati }\end{array}$ & Private Bank & \multirow[t]{3}{*}{ Railroads } \\
\hline & Ohio Saving Bank, Cincinnati & Saving Bank & \\
\hline & Kentucky Trust Company & Trust Company & \\
\hline 1857 & $\begin{array}{l}\text { Ohio Life Insurance and Trust } \\
\text { Company, Ohio and New York }\end{array}$ & Trust Company & Railroads \\
\hline
\end{tabular}

Table2: A Survey of America's Most Important Financial Crises ${ }^{22}$

\section{REFERENCE LIST}

Betz Frederick, (2014). Why Bank Panics Matter, Cross-disciplinary Economic Theory, Springer International Publishing, Switzerland,

Calomiris W. C.; Schweikart L., $\left(4^{\text {th }}\right.$ Dec, 1991). The Panics of 1857: Its Origins, Transmission, and

\footnotetext{
18 The Act is also referred to as National Currency Act signed by President Abraham Lincoln.

${ }^{19}$ The greenback had first been seen in American economy during colonial period. It has not been seen again till the Republican Congress introduced it during the Civil War to finance northern warfare.

20 The NBS integrated greenback currency into its assets, a fact that is related to the crash of 1873.

${ }^{21}$ In 1875, Congress passed the resumption Act to enable government to start redeeming greenbacks by 1879 .

${ }^{22}$ Hugh Rockoff, The Failures that Ignited America's Financial Panics: A Clinical Survey, Rutgers University, 2013, pp 40-42.
} 
Containment, in Journal of Economic History 51:807-834,

Castells M, Caraça J., Cardoso G. (Eds). (2012).The Cultures of the Economic Crisis: An Introduction, Oxford University Press, UK,

Houstan J.L. (1987). The Panic of 1857 and the Coming of the Civil War, Louisiana State University Press,

Rothbard N. Murray. (1962).The Panic of 1819: Reactions and Policies, Columbia University Press, USA,

Trask H.A. Scott. (March 2002). The Panic of 1837 and the Contraction of 1839-43: a Reassessment of its Causes from an Austrian Perspective and a Critique of Free Banking Interpretation, Kurzweg Fellow, Mises Institue, 